\title{
THE PERCEPTIONS OF STUDENTS AND TEACHERS ABOUT THE LEVEL OF THE SANCTIONS FOR ACADEMIC INTEGRITY VIOLATIONS: AN EXPLANATORY SEQUENTIAL DESIGN STUDY IN A NURSING EDUCATION PROGRAM
}

\author{
Yogik Setia Anggreini*, Yayi Suryo Prabandari**, Titi Savitri Prihatiningsih** \\ * Master in Medical Education, Faculty of Medicine, Universitas Gadjah Mada, Yogyakarta - INDONESIA \\ ** Faculty of Medicine, Universitas Gadjah Mada, Yogyakarta - INDONESIA
}

\begin{abstract}
Background: Professional Behavior is a reflection of the professionalism, which includes academic integrity. Some of student's behavioral violations related to academic integrity are influenced by perception. However, students and lecturers tend to interpret these violations differently associated with severity of academic integrity, for example, the sanction against violations of academic integrity. Thus, these differences may contribute to the number of occurrences of academic integrity violations. This study aims to identify the perception of nursing students and lecturers about the level of sanctions for violations of academic integrity.

Method: This study used a mixed method using a sequential explanatory design. This was also a quantitative research survey using a questioner to 101 nursing students, followed by focus group discussion done by the students and in-depth interviews to four lecturers.

Results: The behavior deemed not to be in violation was 1\% -5.9\%. Most students chose sanction level $2(21.8 \%-66.35 \%)$, sanction level $3(23.8 \%-28.7 \%)$ and the highest sanction level or level 10 (19.8\%)

Conclusion: The perception of students to the sanction level out of 22 items, 15 items nursing students chose sanction level 2 "verbal warning" (21.8\% - 66.35\%), 2 items students chose sanction level 3 "written warning" (23.8\% -28.7\%). The highest sanction level chosen was level 10 "reported to the professional regulatory body" (19.8\%). The lecturers assumed that mild sanction first given was in the form of verbal warning and the toughest was being suspended.
\end{abstract}

Keywords: academic integrity, perception, the level of sanctions

\section{ABSTRAK}

Latar belakang: Perilaku profesional merupakan sebuah cerminan dari profesionalisme, yang didalamnya termasuk integritas akademik. Beberapa pelanggaran perilaku mahasiswa terkait dengan integritas akademik dipengaruhi oleh persepsi. Namun, mahasiswa dan dosen cenderung menafsirkan berbeda terkait dengan integritas akademik misalnya berat ringannya sanksi yang diberikan terhadap pelanggaran integritas akademik, sehingga perbedaan tersebut dapat berperan terhadap jumlah kejadian pelanggaran integritas akademik. Penelitian ini bertujuan untuk mengetahui persepsi mahasiswa dan dosen keperawatan tentang level sanksi pelanggaran integritas akademik.

Metode: Penelitian yang akan dilakukan merupakan penelitian mixed method yang menggunakan strategi sequential explanatory design. Penelitian kuantitatif survei dengan menggunakan kuasioner terhadap 101 mahasiswa keperawatan, kemudian dilakukan setelah analisis kuantitatif dilakukan FGD pada mahasiswa dan wawancara mendalam kepada 4 dosen.

contact: yogik.setia89@gmail.com 
Hasil: Perilaku yang dianggap tidak melanggar (1\%-5.9\%). Sebagian besar mahasiswa memilih level sanksi 2 $(21,8 \%-66,35 \%)$, level sanksi $3(23,8 \%-28,7 \%)$ dan Level sanksi tertinggi yang dipilih mahasiswa adalah level $10(19,8 \%)$

Kesimpulan: Persepsi mahasiswa terhadap level sanksi dari 22 item, 15 item mahasiswa keperawatan memilih level sanksi 2 (21,8\% - 66,35\%), 2 item pernyataan mahasiswa memilih level sanksi 3 "peringatan tertulis" (23,8\%-28,7\%). Level sanksi tertinggi yang dipilih mahasiswa adalah level 10 "dilaporkan pada badan pengaturan profesional" pada item pernyataan (19,8\%). Dosen beranggapan bahwa sanksi ringan yang diberikan pertama kali berupa teguran lisan dan yang terberat berupa skores

Kata kunci: academic integrity, persepsi, level sanksi

\section{INTRODUCTION}

Academic integrity is an important part of various disciplines in higher education institutions in many countries, including Indonesia. ${ }^{1.4}$ Academic integrity in higher education life is difficult to maintain, for example by the practice of many forms of fraud and dishonesty to achieve the objectives in learning. ${ }^{3}$ Academic integrity is a commitment to face difficulties and has 6 core values, they are honesty, trust, fairness, respect, responsibility, and courage. ${ }^{5}$

Academic integrity plays an important role in the nursery world. It is because academic integrity is the reflection of professional behavior and is seen as a need to be added into formal nursery learning activities. It is expected to be able to shape professional nursery students. According to Roff et al, the manifestation of many behaviors that put forward the principles of academic integrity is the embodiment of the first stage of professional behavior development of a student. ${ }^{3,4}$

Academic integrity and professionalism as well as professional behavior have a strong relationship because: 1) the core values of academic integrity are components of professionalism; 2) professionalism may only be established if professional behavior, including academic integrity, is done continuously; 3 ) professional attitude and behavior must be developed since being a student through the commitment and efforts to establish academic integrity. ${ }^{6}$

According to Geddes (2011) cit. Ronokusumo et al. (2012), academic integrity violations that are commonly found are fraud (asking another person to perform one's task and submitting it under one's name), plagiarism, cheating, fabrication (data or citations manipulation in a report), stealing and propagating exam materials, falsifying the signatures of the authority in academic documents, using technology to get answers during exams, and using unpermitted notes. ${ }^{3}$

A study on 688 nursery students in Western Cape showed that $88 \%$ of the respondents had performed cheating at least one time and performed plagiarism (60\% of the respondents). ${ }^{7}$ Likewise, a study on 274 medical students from 3 faculties of medicine in Karachi, Pakistan found that $44.02 \%$ of the respondents in clinical rotation faked stories about patients' history, $85.7 \%$ signed for their absent friends, and $51.1 \%$ cheated on tests. ${ }^{8}$

According to above description, it showed that many occurrences related to academic integrity violations becomes a problem and a challenge for education institutions, including teachers, because teachers are role models for students and higher education institutions are the focus of intellectual, moral, and socio-cultural development of students, ${ }^{9}$ so it is important for teachers to always behave and act in accordance with academic honesty as well as prevent students to do things related to academic dishonesty.

One of the causes of students' academic dishonesty is affected by students' and teachers' perception., ${ }^{4,10,11}$ Different perceptions between students and teachers related to academic integrity may influence the number of academic integrity violation occurences ${ }^{10}$ because one's behavior is affected by their way to see something, so perceptions and behavior are two related things and may affect someone's cheating. ${ }^{11,12}$ 
According to McKay et al. (2007); Robinson-Zanartu et al. (2005) cit. Zivcakova et al. (2012), teachers' perceptions related to the level of sanctions for academic integrity violations are various and tend to be very light and also would affect students to violate academic integrity. ${ }^{13}$ Likewise, students cheat because of the lightness of the sanctions in their perceptions. ${ }^{11}$ When students know that the faculty (teachers) tend to ignore academic integrity violations and give light sanctions, students would ignore things related to academic integrity violations. In a study by Roff (2011), 47\% of faculty respondents responded the importance of academic integrity education as well as its sanctions, ${ }^{14}$ because the understanding of perceptions about academic dishonesty and its sanctions is an important first step to develop the strategies to reduce the occurrences of academic dishonesty. ${ }^{15}$

According to above descriptions, the arising problem is the understanding of the perceptions of students and teachers about the level of sanctions for academic integrity violations in Indonesian context in nursery students, so that this study aims to know the perceptions of teachers and students about the level of sanctions for academic integrity violations.

\section{METHODS}

The design of this study is a non-experimental study with quantitative and qualitative methods. This study began with a descriptive quantitative method and was continued with a qualitative method. Qualitative approach was used to enhance, interpret, and explain the quantitative data analysis further. A mixed-method study begun by a quantitative study using data from a questionnaire that was then analyzed and its results used for a qualitative study is called a sequential explanatory strategy. ${ }^{16}$

In the quantitative stage, a cross-sectional design was used to depict a certain population in a certain time and this time period was short. ${ }^{17}$ In the qualitative stage, authors used interviews to nursery teachers and focus group discussion (FGD) using an interview guide made by the authors.

This study involved 101 fourth-year nursery students and 4 nursery teachers. The number of students taking part in the FGD was 16 students, divided into 2 groups. Each group had 9 and 7 students in it.

The instrument used in this study was "Dundee Polyprofessionalism Survey I: Academic Integrity" developed by Roff (2012) and consists of 34 question items. This instrument was modified to make it easy for the respondents to fill it and it went through validity and reliability tests in Indonesian language. Valid items were items that had corrected item-total correlation $r_{\text {count }}>r_{\text {table }}$, with $r>0.1956$ (for $\left.n=101\right)$ and Cronbach’s alpha ( $\square$ Cronbach $=0.934)$.

Qualitative data was obtained from focus group discussions (FGDs) to students and interviews to teachers with established criteria. This study used an interview guide made by authors consisting of open semi-structured questions to explore the perceptions of students and teachers about the level of sanctions for academic integrity violations.

Descriptive data analysis was used to know the perception of students about the behaviors considered as violations as well as the selected sanctions. The level of sanctions selected by students were: Level 1 (no sanctions) to Level 10 (reported to professional regulatory body). Qualitative data was used to know teachers' perceptions about academic integrity. The process of qualitative analysis consisted of several steps, they were transcribing interview results, coding, and finding the theme.

Authors presented the whole quantitative and qualitative data as well as unified the quotations of the qualitative results to clarify the quantitative results. Furthermore, authors also involved an interrater during coding, categorization, and theming processes. At data interpretation stage, authors rechecked the obtained results analysis to make sure that the results had answered the study questions. Results interpretation was also used to see other supporting studies point of view and several theories written by authors, so the results might be presented comprehensively, either the qualitative or quantitative ones, to facilitate the understanding of the authors or readers.

This study was conducted after getting the permission from the research institution and obtaining an ethical clearance from the Ethical Committee. All 
participants were involved in this study voluntarily. The consent to take part in this study was proven by the students' signature on the informed consent after they were informed about the background, aims, and benefits of the study, as well as the confidentiality.

\section{RESULTS AND DISCUSSION}

The majority of the respondents were female (92.1\%). 52 respondents had CGPA $\geq 3.50$ (51.5\%). Of the responding teachers in this study, 2 were male teachers and 2 were female. 2 of the responding teachers in this study were 32 years old, 1 was 33 years old, and 1 was 45 years old. Each of them had teaching experiences for more than 5 years.

Of the 22 statement items depicting academic integrity behavior considered as wrong, there were 15 questions items with sanction level 2 as the sanction selected by the students (see Table 1). Here are the top 5 behaviors considered as wrong, but students selected light sanctions for them (Level $2=$ oral warning).

Table 1. Students' perceptions about academic integrity and the level of sanctions

\begin{tabular}{|c|c|c|c|c|}
\hline \multirow{2}{*}{ Statement } & \multicolumn{3}{|c|}{ Is this wrong? } & \multirow{2}{*}{$\begin{array}{l}\text { Level of } \\
\text { sanction } \\
2\end{array}$} \\
\hline & No & Uncertain & Certain & \\
\hline Often coming late to class & 4.0 & 13.9 & 82.2 & 66.3 \\
\hline $\begin{array}{l}\text { Getting or giving help for assignments, breaking } \\
\text { teachers' rules (e.g.: lending an assignment/task for } \\
\text { other students to cheat) }\end{array}$ & 3.0 & 15.8 & 81.2 & 65.3 \\
\hline $\begin{array}{l}\text { Not doing one's part of the task in a group } \\
\text { assignment }\end{array}$ & 0 & 6.9 & 93.1 & 53.5 \\
\hline $\begin{array}{l}\text { Displacing an assigned reference in the library shelf } \\
\text { to prevent other students to get information from } \\
\text { that certain reference }\end{array}$ & 5.0 & 16.8 & 78.2 & 59.4 \\
\hline $\begin{array}{l}\text { Signing the list of attendees for (an) absent } \\
\text { friend(s), or asking a classmate to sign the list of } \\
\text { attendees for you in laboratory or class }\end{array}$ & 5.9 & 5.0 & 89.1 & 53.5 \\
\hline
\end{tabular}

The interesting thing according to Table 2 above is that signing the list of attendees for an absent friend or asking a classmate to sign the list of attendees for you in laboratory or class was an attitude considered as non-violating for a few students (5.9\%). This was in accordance with a confession by students during FGDs that they had ever asked a classmate to sign for them and signed for an absent friend, although they realized that asking a friend to sign for them or signing for an absent friend was a wrongdoing.

"What experience? Maybe signing for an absent friend or asking for a friend to sign for me, Sis. Maybe a friend couldn't come to class..." $\left(r 3_{m} k 1\right)$ "...so now I feel that asking for a friend to sign for me is a mistake, like that." ( $\left.r 16_{m} \mathrm{k} 2\right)$

According to Table 2, there is another interesting point where students realized that those behaviors were wrong, but students selected light sanctions for them (oral warning). Oral warning sanction was most assigned to: 1) often coming late (66.3\%); 2) getting or giving help for assignments, breaking teachers' rules (e.g.: lending an assignment/task for other students to cheat) (65.3\%). 
The results of the interviews to teachers related to the sanctions for the students caught signing for an absent friend would be admonition as the first warning.

"yes, err, maybe the first would be admonition, it is in the grade recap too, no, the presence recap..." (r1q6)

Teachers realized that unstrict sanctions might cause academic integrity violations, especially in group tasks because it was difficult to detect. Unstrict and different sanctions among teachers also caused students to belittle the sanctions. Moreover, problems related to indiscipline still often occur in students and in teachers themselves.

"the student did the group assignment, err, but after the grade was issued it was revealed that he/she actually did not do the task. However, in the assignment there was his/her name. This information arises, but we can't actually crack him/her down, we still don't know what to do with this..." (r1q6)

"Yes, some teachers are strict and don't allow students to enter class if they are late for more than 15 minutes, sometimes they even lock the door. I myself let them in when they're late. I can't do that because I realize that sometimes I also come late to teach them. For example, I come at 9 when I'm supposed to teach at 8." (r3q6)

Academic integrity becomes central and has an important role in education institutions, especially in teaching and learning process, so that it is not just students who must have the integrity, but teachers must also be able to establish academic integrity., ${ }^{5,13}$ According to ICAI (2013), the main principle of integrity is to create a successful life, while integrity in academic setting is the basic component of successful learning in class environment, so that it may prepare students to be professional.

Asosiasi Institusi Pendidikan Ners Indonesia (AIPNI) or the association of Indonesian nursery education institutions established the elements of professional behavior as one of nursery passing competence, so that professional behavior is an important thing in nursery, either in international, national, or institutional level. ${ }^{19}$ Academic integrity unites many nursery professionalism values that would only be established if they are done continuously.

One of the causes of academic integrity violations is perception. Students' perception is the foundation of students' behavior. Moreover, the difference of the perceptions between teachers and students will also affect the occurrences of academic integrity violations. ${ }^{4,10,11}$ This study saw the two sides from students and teachers in perceiving the level of sanctions for academic integrity violations.

The perception related to the question in the instrument "Is this wrong?" is a belief of academic practice that is ethically questioned (right or wrong). According to the data described in the results above, there are still a few attitudes that are perceived as not wrong (percentage range of $0.0 \%-5.9 \%$ ). This showed that the perception of the attitude violating academic integrity increased towards better direction because these results are different from the one reported by Musharyanti ${ }^{4}$ that demonstrated that the perception of the attitudes considered as violating were in the range of $5-61 \%$.

The fall of the number of academic integrity violations in nursery students may be because in the learning system, at the beginning of school year, students were exposed to soft skills, learning, professionalism, etc. This is in line with the study by Hutchins \& $\mathrm{Cobb}^{22}$ stating that to establish students' academic integrity and professionalism, academic integrity and professionalism must be applied in an integrated manner to all students and learning places, either in classrooms, laboratories, or clinical education, involving all parties. Furthermore, the decrease of the number of academic integrity violations is in accordance with model 4C (community, core value, commitment, curriculum) in developing and improving academic integrity. However, in the nursery program, the application of the sanctions need to be stricter.

Teachers' perceptions related to academic honesty violations is a serious problem in education institutions. ${ }^{20} \mathrm{~A}$ majority of the teachers handled students' academic dishonesty individually and did not follow it up in the formal way because many teachers considered that students' fraud problems were better to be settled down between teachers and students only. ${ }^{23}$ 
The next results showed students' perceptions about the sanctions given. The sanction found to be selected the most by students was sanction number 2 ("oral warning") as the sanction for academic integrity violations. The selection of sanction number 2 was related to the attitude perception of: 1) often coming late; 2) getting or giving help for assignments, breaking teachers' rules; 3) signing the list of attendees for an absent friend, asking a classmate to sign the list of attendees for you in class; 4) doing other students' tasks; 5) not doing the assigned part of the task in a group assignment.

That list of attitudes demonstrated that students' perceptions considered that those attitudes were wrong. However, with light sanctions, students would belittle them and still violate academic integrity. The results related to the level of the sanctions are in line with the findings by Muktamiroh ${ }^{6}$ who showed that the sanction selected the most was on level 2 "oral warning", even for attitudes such as getting or giving help for assignments, breaking teachers' rules, and citing sources incorrectly students selected sanction level 1 "no sanctions". ${ }^{6}$

The attitude of belittling sanction level is one of the causes of academic integrity violations. From the qualitative results, teachers expressed that unstrict sanctions and rules caused academic integrity violations, same with what the students said.

"...from the beginning we were told that, err, if we attended less than $75 \%$ of the lectures we would not be able to take the exams, but after I calculated I knew I missed more than 25\% of the lectures. I still took the exams, though. Well, the following semester I didn't come to class and didn't ask my friends to sign for me..." $\left(r 13_{m} k 2\right)$

"...it might be the environment, err, but we were also not strict enough..." (r1q5)

Teachers' perceptions related to the level of the sanctions for academic integrity violations varied and tended to be very light. ${ }^{13}$ When students found out that the faculty (teachers) tended to ignore academic integrity violation cases and gave light sanctions, students would ignore the values related to academic integrity violations. According to the results, as a matter of fact, the application of the sanctions was already established in the institutions, including teaching and learning activities. However, in academic integrity situation, strictness, fairness, openness, and discipline in applying sanctions are very important. ${ }^{29}$

In previous studies, a method that might be able to break the chain of academic integrity violations that many suggested was the establishment of strict rules and sanctions to academic integrity violators. The results of this study are also similar with the findings by Theart ${ }^{7}$ that there are a few strategies that may be done to prevent academic integrity violations, such as strict sanctions, assisting students during exams, and reducing student assignments. Aside from strict sanctions, sanctions need to be clear, detailed, and specific. Rules must also be clear and specific. ${ }^{21} \mathrm{~A}$ policy of academic integrity inside it should also have law for the policy violations. The sanctions may be light to severe, adjusted with the violations done.

Furthermore, teachers need to be role models. Role modelling is an important part of the aspects of professionalism and the development of professional and competent behavior, as well as being the method to transmit skills. ${ }^{30}$ The faculty has an important role in the process of creating and maintaining academic integrity in teaching and learning because they will influence students behavior in class. ${ }^{31}$ The results of this study also support the theory of social-cognitive learning, where the behavior of students in learning is from observing others. Therefore, by setting an example to students, it may help students acquire a new behavior, including observing the behavior of cheating done by others that would influence one's tendency to do the same. ${ }^{32,33}$

The development of students' professional behavior that puts forward the principle/value of academic integrity (honesty, fairness, respect, responsibility, belief, and courage) in education environment in academic stage has a strong relationship with influencing students' professional behavior in the professional education stage or in workplace. ${ }^{24.27}$ The outcome of professional behavior includes professionalism, success, and expertise. ${ }^{28}$ 
The effort to inculcate values by giving the concept, understanding, or doctrine (sanctions) may be done in the process of learning, such as putting it in the ethics or soft skills subjects, so it may be the media of inculcating academic integrity values. Moreover, it may be integrated in the teaching process.

This study has several limitations and authors tried to overcome it. Data were collected with quite many items and were filled in a one-time session (in the afternoon after all learning activities), so this might exhaust the respondents. A group filled the questionnaire after an OSCE exam, so this might cause some anxiety in several respondents. Authors overcame this by giving much time for the respondents to fill the questionnaire and they were not rushed.

Data collection was not like what the authors planned, which was in a large class to make the data collection from all the students to be at the same time. However, because of tight schedules and students had finished the block exam, not all students were able to come to campus. To overcome it, authors coordinated with research assistants to coordinate the group chiefs for the free time to fill the questionnaire.

\section{CONCLUSIONS}

Of the 22 statement items, according to students' perception about the level of sanctions, nursery students selected sanction level 2 "oral warning", although they considered it wrong (21.8\% $66.35 \%)$. Students selected 2 statement items with sanction level 3 "written warning" (23.8\% - 28.7\%). The highest level of sanction the students selected was level 10 "reported to professional regulatory body" for the statement item "involved in pedophilic activities" (19.8\%). Teachers' perception about the sanctions for academic integrity violations varied from light to severe. Teachers considered that light sanctions given first was oral warning and the most severe was suspension.

\section{SUGGESTIONS}

A study is needed to be conducted to measure academic integrity perception and link it to other variables such as the assessment type or learning environment with more samples.

\section{REFERENCES}

1. Bolin AU. Self Control, Perceived Opportunity, and Attitudes as Predictor of Academic Dishonesty. The Journal of Psychology, 2004;138(2):101-14.

2. Harding TS, Carpenter DD, Finelli CJ, Passow HJ. Does Academic Dishonesty relate to Unethical Behavior in Professional Practice? An Explanatory Study. Science and Enginering Ethics, 2004;10:31124.

3. Ronokusumo S. Integritas Akademik "Sekedar Kata atau Nyata". Jakarta: Badan Penerbit Fakultas Universitas Indonesia; 2012.

4. Musharyanti L. Persepsi dan Perilaku Mahasiswa Keperawatan tentang Integritas Akademik di Program Studi Ilmu Keperawatan Fakultas Kedokteran Universitas Gadjah Mada: Tesis. Yogyakarta: Universitas Gadjah Mada; 2010.

5. International Center for Academic Integrity. The Fundamental Values of Academic Integrity Second Edition. Illinois: Office of College Relation at Oakton Community College, Des Plaines, Illinois: Clemson University; 2012.

6. Muktamiroh H. Hubungan antara Kapasitas mental dan Kepribadian Dasar Berdasarkan Pengukuran MMPI-2 dengan Persepsi, Perilaku dan Intensi Integritas Akademik Mahasiswa FK UPN Veteran Jakarta: Tesis. Yogyakarta: Universitas Gadjah Mada; 2012.

7. Theart CJ. The Status of Academic Integrity among Nursing Students. Thesis. Master of Nursing. Stellenbosch University; 2011.

8. Hafeez K, Khan M, Laiq-uz-Zaman, Jawaid M, Haroon S. Academic Misconduct among Student in Medical Colleges of Karachi, Pakistan. Pak J Med Sci, 2013;29 (3): 699-702.

9. Steven TN. Promoting A Culture of Integrity: A Study of Faculty and Student Perceptions of Academic Dishonesty at Large Public Midwestern University. Dissertation. University of Missouri-ST. Louis: ProQuest LLC; 2012.

10. Kwong T, Man NH, Mark KP, Wong E. Students' and Faculty's Perception of Academic Integrity in Hongkong. Emerald Insight Group Publishing, 2010;27(5): 341-56.

11. Whitley BE. Factors Associated with Cheating among College Students: A Review. Research in Higher Education, 1998;8(3). 
12. Sarwono SW. Teori-teori Psikologi Sosial. Edisi revisi. Jakarta: PT. Raja Grafindo Persada; 2008.

13. Zivcakova L, Wood E, Baetz-Pasquale DD. How Do Faculty Members Respond to the their Students's Discussions of Academic Misconduct and Academic Integrity?. International Journal for Educational Integrity, 2012;8(1):25-40.

14. Roff S, Dherwani K. Development of Inventory for Polyprofessionalism Lapses at the Proto-professional stage of Health Professions Education Together with Recommended Responses. Med Teach, 2011;33:239. 43.

15. Arhin AO, Jones KA. A Multidiscipline exploration of College Student's Perceptions of Academic Dishonesty: Are Nursing Students Different from Other College Students? Nurse Education Today, 2009;29:710-4.

16. Cresswell JW. Research Design: Pendekatan kualitatif, kuantitatif dan Mixed edisi ketiga. Yogyakarta: Pustaka Pelajar; 2012.

17. Cohen L, Manion L, Morrison K. Research Method in Education, seventh edition, New York: Routledge; 2011.

18. Chapfika B. The Role of Integrity in Higher Education. International Journal for Educational Integrity, 2008;4(1):43-9.

19. AIPNI. Kurikulum Pendidikan Sarjana Keperawatan. Jakarta: AIPNI; 2015.

20. Pincus HS, Schmelkin LP. Faculty Perceptions of Academic Dishonesty: A Multidiscipline Scalling Analysis. Jounal of Higher Education, 2003;74(2).

21. Whitley BE, Spiegel PK. Acadeemic Integrity as an Institutional Issue. Ethics $\mathcal{E}$ Behavior, 2001;11(3):325 42.

22. Hutchis B, Cobb S. When Will We Be Ready for Academic Integrity? Journal of Dental Education, 2008;.

23. McCabe DL, Butterfield KD, Trevino LK. Faculty and Academic Integrity: The Influence of Current Honor Codes and Past Honor Code Experiences. Research in Higher Education, 2003;44(3).

24. Hilbert GA. Involvement of Nursing Student in Unethical Classroom and Clinical Behaviors. Journal of Professional Nursing, 1985;1:230-4.

25. Nonis S, Swift CO. An Examination of the Relations Between Academic Dishonesty and Workplace Dishonesty: A Multicampus Investigation. Journal of Education for Business, 2001;77(2): ProQuest Education Journals pg. 69.
26. Papadakis MA, Hodgson CS, Teherani A, Kohatsu ND. Unprofessional Behavior in Medical School Is Assosiated with Subsequent Disciplinary Action by a State Medical Board. Acad Med, 2004;79:244-9.

27. Rujoiu O, Rujoiu V. Academic Dishonesty and Workplace Dishonesty An Overview. Proceedings of The $8^{\text {th }}$ International Management Conference. Romania; 2014.

28. Woith W, Jenkins SD, Kerber C. Perceptions of Academic Integrity among Nursing Students. Nursing Forum, 2012;47(4).

29. Olasehinde-Williams O. Instituting Academic Integrity In Nigerian Universities: Psychological Perspectives of Morality and Motivation. Journal of Sociology and Education in Africa, 2006;4(2).

30. Byszewski A, Handelman W, McGuinty C, Moineau G. Wanted: Role Models-Medical Students's Perceptions of Professionalism. BMC Medical Education, 2012;12:115.

31. Hulsart R, McCarthy V. Educator's Role in Promoting Academic Integrity. Proceedings of the Allied Academies, 2008;15(2).

32. Bandura A. Handbook of Moral Behavior and Development Volume 1: Theory (Social Cognitive Theory of Moral Thought and Action). Florida International University: Lawrence Erlbaum Associates; 1991.

33. Ormrod JE. Human Learning, $6^{\text {th }}$ edition, USA: Pearson; 2012.

34. Roff S, Chandratilake M, McAleer S, Gibson J. Medical Student Rankings of Proposed Sanction for Unprofessional Behavior relating to Academic Integrity: Result from Scottish Medical School. Scottish Medical Journal, 2012;57:76-9.

35. Resurreccion PF. The Impact of Faculty, Peers and Integrity Culture in the Academe on Academic Misconduct among Filipino Students: An Empirical Study Based on Social Cognitif Theory. International Journal of Academic Research in Business and Social Sciences, 2012;2(2):33-50.

36. International Center for Academic Integrity. The Fundamental Values of Academic Integrity Second Edition. Illinois: Office of College Relation at Oakton Community College, Des Plaines, Illinois: Clemson University; 2013.

37. Elzubeir MA, Rizk DEE. Exploring Perceptions and Attitudes of Senior Medical Students and Interns to Academic Integrity. Med Educ, 2003;37:589-96. 
38. Tippitt MP, Kline JR, Tilghman J, Chamberlain B, Meagher PG. Creating Environment that Foster Academic Integrity. Nursing Education Perspectives, 2009;10(4).
39. Tanner CA. Moral decline or programmatic decision making? Cheating and plagiarism in perspective. Journal of Nursing Education, 2004;43(7):291-2. 